\title{
Respon Pertumbuhan dan Produksi Beberapa Kultivar Padi Gogo Lokal Sultra Terhadap Volume pemberian Air
}

\author{
Respond of the Growth and Production of Local Upland Rice Cultivars Sultra \\ to the Watering Volume
}

\author{
Moizes dos Reis Borromeu ${ }^{1 *}$, I Gusti Rai Sadimantara ${ }^{2}$, Yulius B. Pasolon ${ }^{2}$ \\ ${ }^{1)}$ Alumni Program Studi Agronomi Program Pascasarjana UHO \\ ${ }^{2)}$ Dosen Program Studi Agronomi Program Pascasarjana UHO
}

Diterima: 20 Desember 2017/Disetujui: 10 Juli 2018

\begin{abstract}
The purpose of the study was to find out the respond growth and production of local upland rice Sultra's on the watering volume. The research was conducted in green house sized $4 x 10 \mathrm{~m}$, from April to August 2015. This study tested four (4) cultivation local upland rice Sultra in the pot and treated with sub-optimum and optimal water levels of 25\%,50\%, 100\% and 150\%. The experiment was conducted by using factorial desing of two factors of randoming complete block design (RCBD) with three replications, where first factor is $W$ (water level) is comprised of four levels; W1 (25\%), W2 (50\%), W3 (100\%), and W4 (150\%). Second factor is cultivars upland rice local comprised of four levels; V1 (cultivar pae dai Ngalaru), V2 (cultivar pae Uba), V3 (cultivar pae Bou) and V4 (cultivar pae Bandoeha). The parameter observed were t plant height of the number of maximum tiller, number of leave, dry weight, dry weight of root, number of productive tiller, days to flowering, weight of 1000 rice, number of grain per tiller, the percentage of empty grain per tiller (\%), blossoming age, and number of dry grain per tree. There is an interaction influence of water volume $100 \%$ and cultivation of pae dai Ngalaru to the height to the plant 70 days after planting and cultivating pae Bou to the tiller 70 days after the planting, 50\% of water volume and cultivar of pae Uba to the number of the leaves 70 days after the planting, $25 \%$ water conditions and cultivar pae Bou to empty grain per plant. The effect of dependent water $100 \%$ (W3) gave the good result on the averages of grain per tree to various cultivar of upland rice, water conditions 100\% (W3) gave the best results on the averages of dry weight of the root of 70 days after planting, water conditions 25\% (W1) and cultivar pae Uba (V2) is the longest type average of grain to blossom. The effect of dependent cultivar of pae Uba (V2) gave good result on the averages of dry weight of peak of plant 70 HST, cultivar pae Bou (V3) gave good result on the averages of number of productive tiller, cultivar of pae Bandoeha (V4) gave good result on the averages of weight of grain seed 1000, cultivar pae Bou (V3) gave good result on the averages of grain per tree.
\end{abstract}

Keywords: Upland Rice, Volume Water, Growth and Production

\begin{abstract}
ABSTRAK
Tujuan peneltian ini dilakukan untuk mengetahui respon pertumbuhan dan produksi kultivar padi gogo lokal Sultra terhadap pemberian volume air.Penelitian ini dilaksanakan dirumah plastik ukuran 4 x 10 m, mulai dari bulan April sampai bulan Agustus 2015. Penelitian ini menguji empat (4) kultivar padi gogo lokal Sultra dalam pot dan diberi perlakuan pengkondisian air sub-optimal dan air optimal dengan taraf $25 \%, 50 \%, 100 \%$ dan $150 \%$. Percobaan dilakukan dengan mengunakan rancangan faktorial dua faktor pola Rancangan Acak Kelompok Lengkap (RAKL) dengan tiga ulangan,dimana faktor pertama adalah $\mathrm{W}$ (volume air) terdiri dari empat taraf; W1(25\%), W2 (50\%),W3 (100\%), dan W4(150\%). Faktor kedua yaitukultivar padi gogo terdiri dari empat (4)taraf;V1 (kultivar pae dai Ngalaru), V2 (kultivar pae Uba), V3 (kultivar pae Bou) dan V4 (kultivar pae Bandoeha). Parameter yang diamati: tinggi tanaman, jumlah anakan maksimum, jumlah daun, berat kering tajuk, berat kering akar, jumlah anakan produktif, umur berbunga, bobot 1000 butir, jumlah gabah per malai, persentase gabah hampa per malai (\%), hasil gabah kering perrumpun. Terdapat pengaruh interaksi volume air 100\% dan kultivar pae dai Ngalaru terhadap tinggi tanaman 70 hari setelah tanam dan kultivar pae Bou terhadap jumlah anakan 70 hari setelah tanam, volume air 50\% dan kultivar pae Uba terhadap jumlah daun 70
\end{abstract}

\footnotetext{
${ }^{*}$ Penulis untuk korespondensi. Email bmoisesreis@yahoo.com
} 


\section{J. Berkala Penelitian Agronomi 6 (2) : 25 - 36 (2018)}

hari setelah tanam, kondisi air 25\% dan kultivar pae Bou terhadap gabah hampa per malai. Pengaruh faktor mandiri kondisi air 100\% (W3) memberikan hasil terbaik terhadap rata-rata gabah isi per rumpun pada berbagai kultivar padi gogo,kondisi air 100\% (W3) memberikan hasil terbaik terhadap rata-rata berat kering akar tanaman 70 HST, kondisi air 25\% (W1) dan Kultivar pae Uba (V2) memberikan hasil paling lama terhadap rata-rata umur berbunga. Pengaruh faktor mandiri kultivar pae Uba (V2) memberikan hasil terbaik terhadap rata-rata berat kering tajuk tanaman 70 HST, kultivar pae Bou (V3) memberikan hasil terbaik terhadap rata-rata jumlah anakan produktif, kultivar pae Bandoeha (V4) memberikan hasil terbaik terhadap rata-rata berat gabah 1000 butir, kultivar pae Bou (V3) memberikan hasil terbaik terhadap rata-rata gabah isi per malai.

Kata kunci : Padi Gogo, Volume Air, Pertumbuhan dan Produksi.

\section{PENDAHULUAN}

Padi merupakan bahan makanan pokok bagi sebahagian besar penduduk Asia khususnya Asia Tenggara. Di Indonesia padi merupakan makanan pokok utama, kemudian jagung dan ketela pohon (ubi kayu).Sekitar $90 \%$ produksi dan konsumsi padi berada di Asia.Masalah ketersediaan beras sering menjadi masalah yang cukup memprihatinkan, karena selain perubahan fungsi lahan pertanian menjadi lahan non pertanian, juga akibat timbulnya masalah baru pada beberapa saat terakhir ini seperti adanya musim kering yang panjang yang menyebabkan keterlambatan musim tanam.

Kebutuhan beras di Sulawesi Tenggara semakin meningkat setiap tahunnya seiring dengan peningkatan jumlah penduduk. Berdasarkan data Badan Pusat Statistik Provinsi Sulawesi Tenggara (2014), rata-rata produksi padi gogo di Sulawesi Tenggara relatif meningkat yakni pada tahun 2011 produksi padi gogo mencapai 25.034 ton Gabah Kering Giling dengan luas panen 8.175 ha, selanjutnya di tahun 2012 meningkat menjadi 28.780 ton Gabah Kering Giling dengan luas panen 9.986 ha, dan pada tahun 2013 meningkat menjadi 32.121 ton Gabah Kering Giling dengan luas panen 10.243 ha, yang berarti mengalami peningkatan sebanyak 3.341 ton dibandingkan dengan produksi tahun 2012. Peningkatan produksi tahun 2013 terjadi karena meningkatnya luas panen sebesar 257 ha dan produktivitas meningkat sebesar 0,25 ton ha-1 $(8,67 \%)$.

lahan $\begin{array}{rrr}\text { Namun } & \text { pengembangan padi pada } \\ \text { kering di Sulawesi } & \text { Tenggara }\end{array}$

\section{METODOLOGI PENELITIAN}

Penelitian dilaksanakan di Lahan Praktek Fakultas Pertanian Universitas Halu Oleo pada rumah plastik ukuran $4 \times 10 \mathrm{~m}$, mulai dari bulan April sampai bulan Agustus 2015. Penelitian menguji 4 kultivar padi gogo menghadapi berbagai kendala antara lain karena ketersediaan air menjadi faktor dalam pertumbuhan dan produksi tanaman. Upaya untuk mengatasi masalah ini, yaitu melaksanakan waktu tanam yang tepat untuk menjamin pasokan air yang cukup mulai dari fase vegetatif sampai fase reproduktif, dan pemilihan kultivar tanaman yang toleran terhadap keadaan kurang air

Pada kondisi kekurangan air, akan terjadi penurunan fotosintesis tanaman akibat terjadinya penurunan tekanan potensial daun, aktifitas metabolisme, jumlah daun dan luas daun. Penurunan aktifitas metabolisme selain disebabkan oleh penurunan jumlah dan luas daun, juga akibat penutupan stomata sehingga menyebabkan penurunan biomassa (Rumani, 2003).Semakin tinggi cekaman air mengakibatkan makin rendahnya transpirasi dan meningkatkan difusi daun (Sutoro dan Somadiredjo, 1989).

Padi gogo umumnya ditanam dilahan kering dalam sekali setahun pada awal musim hujan.Rendahnya produksi padi gogo juga disebabkan masih banyaknya yang menanami lahan kering dengan padi gogo varietas lokal yang berumur panjang.Varietas padi gogo tersebut mempunyai beberapa kelemahan seperti tidak tahan rebah, mudah rontok, berdaya hasil rendah dan umumnya kurang toleran terhadap kekeringan (Prasetyo, 2002).

Tujuan Penelitian Untuk mengetahui pengaruh interaksi volume air dan kultivar, pengaruh kondisi air, dan pengaruh kultivar terhadap pertumbuhan dan produksi padi gogo lokal.

lokal SULTRA dalam pot dan diberi perlakuan pengkondisian air sub-optimal dan air optimal dengan taraf $25 \%, 50 \%, 100 \%$ dan $150 \%$.

Bahan yang digunakan adalah kultivar (pae dai Nggalaru, pae Uba, pae Bou, dan pae Bandoeha), tanah topsoil, pupuk NPK Jerman, 
pupuk urea, air, sedangkan alat yang digunakan adalah Pot ukuran $25 \mathrm{~cm}$ x $30 \mathrm{~cm}$, label, cangkul, parang, sekop, kayu patok, tali rafiah, kamera, alat tulis, pengaris, laptop, meter rol, paranet dan plastik, timbangan biasa dan timbangan analitik, cetok, dan termometer suhu.Percobaan dilakukan dengan mengunakan rancangan faktorial dua faktor pola RAKL dengan tiga ulangan,dimana faktor pertama yaitu faktor W (volume air yang terdiri dari empat taraf yaitu W1 $(25 \%)$, W2 $(50 \%)$, W3 (100\%), dan W4 (150\%). Faktor kedua yaitu kultivar padi gogo terdiri dari empat (4) taraf, yaitu V1 (kultivar Ngalaru), V2 (kultivar pae Uba), V3 (kultivar pae Bou) dan V4 (kultivar pae Bandoeha).Setiap satu satuan percobaan terdiri dari 2 pot jadi total pot pada percobaan adalah $48 \times 2=96$ pot.

Jenis pengamatan dan waktu pengamatan meliputi: Tinggi tanaman $(\mathrm{cm})$,

\section{HASIL DAN PEMBAHASAN}

\section{Tinggi Tanaman}

Pengaruh interaksi kondisi air dan kultivar padi gogo lokal serta hasil uji jarak berganda Duncan (UJBD) 70 HST disajikan pada Tabel 1.

Tabel 1 menunjukkan bahwa kondisi air 100\% dan kultivar pae dai ngalaru (W3V1) memberikan hasil terbaik terhadap rata-rata tinggi tanaman 70 HST yang berbeda nyata dengan kondisi air 25\% dan kultivar pae dai Ngalaru (W1V1), kondisi air $150 \%$ dan kultivar pae dai Ngalaru (W4V1), kondisi air 100\% dan kultivar pae Uba (W3V2), kondisi air $100 \%$ dan kultivar pae Bou (W3V3) dan kondisi air $100 \%$ dan kultivar Bandoeha diukur pada umur 70 hari setelah tanam (HST), Jumlah anakan produktif dihitung pada saat menjelang panen, Biomasa Tanaman akar, batang, daun. Umur berbunga ditentukan apabila malai dari sejumlah anakan telah muncul, umur panen dihitung pada saat panen,Bobot 1000 Butirdihitung setelah panen, Jumlah Gabah Permalai dihitung setelah panen. Persentase Gabah Isi Permalai (\%) di hitung setelah panen, Hasil Gabah Kering Perrumpun dihitung setelah panen

Data yang diperoleh dianalisis dengan menggunakan uji $F$ (Sidik ragam) untuk mengetahui tingkat signifikansi masingmasing faktor perlakuan dan interaksinya terhadap variabel yang diamati dengan menggunakan aplikasi SAS. Apabila terdapat perbedaan yang nyata maka dilanjutkan dengan Uji Jarak Berganda Duncan pada taraf 95\% (UJBD 0,05).

(W3V4) tetapi tidak berbeda nyata dengan kondisi air 50\% dan kultivar pae dai Ngalaru (W2V1). Hal ini menunjukkan bahwa tanaman yang kebutuhan airnya tersedia secara cukup selama pertumbuhan akan melakukan prosesproses fisologis secara maksimal sehingga pertumbuhan morfologi tanaman menjadi optimal. Tanaman yang mengalami defisit atau surplus air pada masa pertumbuhannya akan mengalami penghambatan pertumbuhan karena air berperan penting dalam proses pembentukan organ, fotosintesis yang digunakan untuk pembentukan makanan bagi tanaman.

Tabel 1 Pengaruh interaksi kondisi air dan kultivar terhadap tinggi tanaman padi gogo 70 HST $(\mathrm{cm})$

\begin{tabular}{|c|c|c|c|c|c|c|}
\hline Perlakuan & $25 \%$ & $50 \%$ & $100 \%$ & $150 \%$ & Rerata & UJBD \\
\hline \multirow[t]{2}{*}{ Pae ngalaru } & $137.70 \mathrm{a}$ & $146.667 \mathrm{a}$ & $153.250 \mathrm{a}$ & $142.000 \mathrm{a}$ & 144.917 & $2=14.282$ \\
\hline & $q$ & $\mathrm{pq}$ & $\mathrm{p}$ & $\mathrm{pq}$ & & $3=14.888$ \\
\hline \multirow[t]{2}{*}{ Pae uba } & $152.583 \mathrm{a}$ & $143.000 \mathrm{a}$ & $133.167 \mathrm{bc}$ & $138.083 \mathrm{ab}$ & 141.708 & $4=15.297$ \\
\hline & $\mathrm{p}$ & $\mathrm{pq}$ & $q$ & $\mathrm{pq}$ & & \\
\hline \multirow[t]{2}{*}{ Pae bou } & $122.083 \mathrm{~b}$ & $133.833 \mathrm{a}$ & $118.917 \mathrm{c}$ & $124.667 \mathrm{~b}$ & 124.875 & \\
\hline & $\mathrm{p}$ & $\mathrm{p}$ & $\mathrm{p}$ & $\mathrm{P}$ & & \\
\hline \multirow[t]{2}{*}{ Pae bandoeha } & $147.250 \mathrm{a}$ & $142.417 \mathrm{a}$ & $139.083 \mathrm{ab}$ & $129.500 \mathrm{ab}$ & 139.563 & \\
\hline & $\mathrm{p}$ & $\mathrm{pq}$ & $\mathrm{pq}$ & $q$ & & \\
\hline Rerata & 139.917 & 141.479 & 136.104 & 133.563 & & \\
\hline
\end{tabular}




\section{Jumlah Daun}

Pengaruh interaksi kondisi air dan kultivar padi gogo lokal terhadap jumlah daun tanaman serta hasil uji jarak berganda Duncan (UJBD 70 HST disajikan pada Tabel 2

Tabel 2 menunjukkan bahwa kondisi air $50 \%$ dan kultivar pae Uba (W2V2) memberikan hasil terbaik terhadap rata-rata jumlah daun tanaman 70 HST yang berbeda nyata dengankondisi air 25\% dan kultivar pae Uba (W1V2), kondisi air 100\% dan kultivar pae Uba (W3V2), kondisi air $150 \%$ dan kultivar pae Uba (W4V2), kondisi air 50\% dan kultivar pae dai Ngalaru (W2V1), kondisi air $50 \%$ dan kultivar pae Bou (W2V3) dan kondisi air $50 \%$ dan kultivar Bandoeha (W2V4).
Hasil penelitian menunjukkan bahwa rata-rata jumlah daun kultivar pae Uba pada kondisi air 50\% memberikan hasil tertinggi dibandingkan dengan kultivar lain pada penelitian ini pada semua kondisi air yang diperlakukaan. Kultivar pae Uba menunjukkan interaksi positif dengan kondisi air 50\% karena kultivar pae Uba yang jumlah daunnya cukup rendah pada kondisi air 25\%, 100\% dan $150 \%$ mengalami peningkatan jumlah daun ketika berada pada kondisi air 50\%. Ketersediaan air yang cukup pada setiap fasefase pertumbuhan tanaman akan mendukung peningkatan pertumbuhan bagian-bagian vegetatif tanaman jika dibandingkan dengan tanaman yang kekurangan atau kelebihan air.

Tabel 2. Pengaruh interaksi kondisi air dan kultivar terhadap jumlah daun tanaman padi gogo 70 HST (helai)

\begin{tabular}{|c|c|c|c|c|c|c|}
\hline Perlakuan & $25 \%$ & $50 \%$ & $100 \%$ & $150 \%$ & Rerata & UJBD \\
\hline \multirow[t]{2}{*}{ Pae ngalaru } & $5.583 \mathrm{a}$ & $5.417 \mathrm{~b}$ & $5.750 \mathrm{a}$ & $5.333 \mathrm{ab}$ & 5.521 & $2=0.575$ \\
\hline & $\mathrm{p}$ & $\mathrm{p}$ & $\mathrm{p}$ & $\mathrm{p}$ & & $3=0.599$ \\
\hline \multirow[t]{2}{*}{ Pae uba } & $5.667 \mathrm{a}$ & $6.417 \mathrm{a}$ & $5.667 \mathrm{a}$ & $5.750 \mathrm{ab}$ & 5.875 & $4=0.616$ \\
\hline & $\mathrm{q}$ & $\mathrm{p}$ & $\mathrm{q}$ & $q$ & & \\
\hline \multirow[t]{2}{*}{ Pae bou } & $5.750 \mathrm{a}$ & $5.917 \mathrm{ab}$ & $5.333 \mathrm{a}$ & $5.917 \mathrm{a}$ & 5.729 & \\
\hline & $\mathrm{p}$ & $\mathrm{p}$ & $\mathrm{p}$ & $\mathrm{p}$ & & \\
\hline \multirow[t]{2}{*}{ Pae bandoeha } & $6.083 \mathrm{a}$ & $5.667 \mathrm{~b}$ & $5.500 \mathrm{a}$ & $5.250 \mathrm{~b}$ & 5.625 & \\
\hline & $\mathrm{p}$ & $\mathrm{pq}$ & $\mathrm{pq}$ & $q$ & & \\
\hline Re rata & 5.771 & 5.854 & 5.563 & 5.563 & & \\
\hline
\end{tabular}

\section{Jumlah Anakan}

Pengaruh interaksi kondisi air dan kultivar padi gogo lokal terhadap jumlah daun tanaman serta hasil uji jarak berganda Duncan (UJDB) 70 HST disajikan pada Tabel 3. Tabel 3 menunjukkan bahwa kondisi air $100 \%$ dan kultivar pae Bou (W3V3) memberikan hasil terbaik terhadap rata-rata jumlah anakan tanaman 70 HST yang berbeda nyata dengan kondisi air 25\% dan kultivar pae Bou (W1V3), kondisi air 50\% dan kultivar pae Bou (W2V3), kondisi air 150\% dan kultivar pae Bou (W4V3), Kondisi air 100\% dan kultivar pae dai Ngalaru (W3V1), kondisi air $100 \%$ dan kultivar pae Uba (W3V2) dan kondisi air $100 \%$ dan kultivar Bandoeha (W3V4).

Hal ini menunjukan secara genetik kultivar ini memiliki keunggulan dari kultivar lain dalam hal jumlah anakan maksimum sehingga berpengaruh pada jumlah anakan yang dibentuk. Hal ini diduga kemampuan kultivar pae Bou dapat beradaptasi dalam lingkungan dan mempunyai kemampuan dalam hal memaksimalkan penyerapan jumlah air yang tersedia secara cukup. 
Tabel 3. Pengaruh interaksi kondisi air dan kultivar terhadap jumlah

anakan tanaman padi gogo 70 HST (anakan)

\begin{tabular}{|l|c|c|c|c|c|c|}
\hline Perlakuan & $\mathbf{2 5 \%}$ & $\mathbf{5 0 \%}$ & $\mathbf{1 0 0 \%}$ & $\mathbf{1 5 0 \%}$ & Rerata & UJBD \\
\hline Pae ngalaru & $12.250 \mathrm{~b}$ & $15.083 \mathrm{a}$ & $12.667 \mathrm{~b}$ & $16.250 \mathrm{a}$ & $\mathbf{1 4 . 0 6 3}$ & $2=4.078$ \\
\hline & $\mathrm{p}$ & $\mathrm{p}$ & $\mathrm{p}$ & $\mathrm{p}$ & & $3=4.251$ \\
\hline Pae uba & $9.833 \mathrm{~b}$ & $12.417 \mathrm{a}$ & $13.250 \mathrm{~b}$ & $12.500 \mathrm{a}$ & $\mathbf{1 2}$ & $4=4.368$ \\
\hline & $\mathrm{p}$ & $\mathrm{p}$ & $\mathrm{p}$ & $\mathrm{p}$ & & \\
\hline Pae bou & $17.583 \mathrm{a}$ & $16.167 \mathrm{a}$ & $21.167 \mathrm{a}$ & $16.250 \mathrm{a}$ & $\mathbf{1 7 . 7 9 2}$ & \\
\hline & $\mathrm{pq}$ & $\mathrm{q}$ & $\mathrm{p}$ & $\mathrm{q}$ & & \\
\hline Pae bandoe ha & $13.000 \mathrm{a}$ & $13.417 \mathrm{a}$ & $13.167 \mathrm{~b}$ & $14.500 \mathrm{a}$ & $\mathbf{1 3 . 5 2 1}$ & \\
\hline & $\mathrm{p}$ & $\mathrm{p}$ & $\mathrm{p}$ & $\mathrm{p}$ & & \\
\hline Re rata & $\mathbf{1 3 . 1 6 7}$ & $\mathbf{1 4 . 2 7 1}$ & $\mathbf{1 5 . 0 6 3}$ & $\mathbf{1 4 . 8 7 5}$ & & \\
\hline Keterangan : Angka-angka yang diikuti oleh huruf yang tidak sama pada kolom yang sama (p-q)dan baris yang \\
sama (a-b) berbeda nyata pada UJBD 0,05
\end{tabular}

\section{Berat Kering Tajuk}

Pengaruh mandirikultivar padi gogo lokal terhadap berat kering tajuk tanaman serta hasil uji jarak berganda Duncan (UJDB) 70 HST disajikan pada Tabel 4.

Tabel 4 menunjukkan bahwa kultivar pae Uba (V2) memberikan hasil terbaik terhadap rata-rata berat kering tajuk tanaman 70 HST yang berbeda nyata dengankultivar pae Bou (V3), kultivar Bandoeha (V4), tetapi berbeda tidak nyata dengan kultivar dai Ngalaru (V1). Kultivar dai Ngalaru (V1) tidak berbeda nyata dengan kultivar pae Bou (V3) dan kultivar Bandoeha (V4).
Hal ini menunjukan bahwa secara genetik kultivar yang diuji berbeda responnya terhadap lingkungan yang sama dalam berat kering tajuk padi serta dapat beradaptasi dengan baik sehingga dapat berpengaruh terhadap berat kering tajuk. Keadaan tersebut mendorong proses metabolisme yang terjadi pada tubuh tanaman akan semakin meningkat, termasuk fotosintesis, mengakibatkan semakin tinggi laju fotosintesis. Semakin banyak fotosintat yang yang terbentuk maka banyak fotosintat yang dihasilkan dan berat kering tanaman akan semakin tinggi.

Tabel 4 Pengaruh mandiri kultivar terhadap berat kering tajuk tanaman padi gogo 70 HST (g)

\begin{tabular}{|l|c|c|c|c|c|c|}
\hline Perlakuan & $\mathbf{2 5 \%}$ & $\mathbf{5 0 \%}$ & $\mathbf{1 0 0 \%}$ & $\mathbf{1 5 0 \%}$ & Re rata & UJBD \\
\hline Pae ngalaru & 75.67 & 90.37 & 87.03 & 105.1 & $\mathbf{8 9 . 5 4} \mathbf{a b}$ & $2=12.12$ \\
\hline Pae uba & 94.53 & 94.37 & 88.03 & 109.33 & $\mathbf{9 6 . 5 7} \mathbf{a}$ & $3=12.74$ \\
\hline Pae bou & 77.12 & 88.03 & 86.93 & 72.03 & $\mathbf{8 1 . 0 3 ~ b}$ & $4=13.14$ \\
\hline Pae bandoeha & 72.07 & 78.4 & 90.6 & 75.57 & $\mathbf{7 9 . 1 6} \mathbf{b}$ & \\
\hline Rerata & $\mathbf{7 9 . 8 5}$ & $\mathbf{8 7 . 7 9}$ & $\mathbf{8 8 . 1 5}$ & $\mathbf{9 0 . 5 1}$ & $\mathbf{8 6 . 5 7}$ & \\
\hline Keterangan :Angka-angka yang diikuti oleh huruf yang tidak sama pada kolom yang sama (a-b) berbeda nyata \\
pada UJDD 0,05
\end{tabular}

\section{Berat Kering Akar}

Pengaruh mandiri kondisi air dan mandiri kultivar padi gogo lokal terhadap berat kering tajuk tanaman serta hasil uji jarak berganda Duncan (UJDB) 70 HST disajikan pada Tabel 5. Tabel 5 menunjukkan bahwa kondisi air $100 \%$ (W3) memberikan hasil terbaik terhadap rata-rata berat kering akar tanaman 70 HST yang berbeda nyata dengankondisi air 25\% (W1) tetapi berbeda tidak nyata dengan kondisi air 50\% (W2) dan kondisi air 150\% (W4). Kultivar pae Uba (V2) memberikan hasil terbaik terhadap rata-rata berat kering akar tanaman 70 HST yang berbeda nyata dengan kultivar pae Bou (V3), tetapi berbeda tidak nyata dengan kultivar dai Ngalaru (V1) dan kultivar pae Bandoeha 
(V4). Kultivar Bandoeha (V4) berbeda tidak nyata dengan kultivar pae Bou (V3).

Hal ini menunjukan bahwa penurunan berat kering akar secara nyata pada semua kultivar karena dipengaruhi oleh sifat genetik dari tiap kultivar. Dari hasil penelitian ini diketahui bahwa ada suatu kecenderungan, berat kering akar akan semakin menurun dengan semakin menurunnya kadar air.

Tabel 5 Pengaruhmandiri kultivar dan kondisi air terhadap berat kering akar tanaman padi gogo 70 HST (g)

\begin{tabular}{|l|c|c|c|c|c|c|}
\hline Perlakuan & $\mathbf{2 5 \%}$ & $\mathbf{5 0 \%}$ & $\mathbf{1 0 0 \%}$ & $\mathbf{1 5 0 \%}$ & Re rata & UJBD \\
\hline Pae ngalaru & 36.47 & 44.83 & 55.6 & 55.6 & $\mathbf{4 8 . 1 3}$ a & $\mathbf{2 = 8 , 0 1}$ \\
\hline Pae uba & 40.57 & 48.27 & 61.93 & 67.2 & $\mathbf{5 4 . 4 9}$ a & $\mathbf{3 = 8 , 4 1}$ \\
\hline Pae bou & 30.63 & 45.2 & 49.03 & 37.2 & $\mathbf{4 0 . 5 2} \mathbf{b}$ & $\mathbf{4 = 8 , 6 8}$ \\
\hline Pae bandoe ha & 33.47 & 59.77 & 38.47 & 42.43 & $\mathbf{4 3 . 5 3}$ ab & \\
\hline Re rata & $\mathbf{3 5 . 2 8} \mathbf{b}$ & $\mathbf{4 9 . 5 2}$ a & $\mathbf{5 1 . 2 6} \mathbf{a}$ & $\mathbf{5 0 . 6 1}$ a & $\mathbf{4 6 . 6 7}$ & \\
\hline \multicolumn{6}{|l|}{ Keterangan : Angka-angka yang diikuti oleh huruf yang tidak sama pada kolom yang sama (a-b) berbeda nyata } \\
pada UJBD 0,05
\end{tabular}

\section{Jumlah Anakan produktif}

Pengaruh mandiri kultivar terhadap jumlah anakan produktif tanaman serta hasil uji jarak berganda Duncan (UJDB) disajikan pada Tabel 6.

Tabel 6 menunjukkan bahwa kultivar pae Bou (V3) memberikan hasil terbaik terhadap rata-rata jumlah anakan produktif yang berbeda nyata dengankultivar pae dai Ngalaru (V1), kultivar pae Uba (V2) dan kultivar pae Bandoeha (V4).

Hal ini diduga merupakan alah satu daya adaptasi padi gogo terhadap kondisi air suboptimal dan optimal, karena setiap kultivar tanaman memiliki kemampuan untuk menghasilkan anakan yang berbeda-beda berdasarkan pada potensi genetik yang dimilikinya. Matsuo dan hoshikawa (1993), berpendapat bahwa yang tergolong genotif padi gogo yang tahan kekeringan akan mempunyai jumlah anakan yang rendah dengan penurunan laju yang rendah pula, penurunan jumlah anakan selaras dengan penurunan lengas tanah.

Tabel 6 Pengaruh mandiri kultivar terhadap jumlah anakan produktif tanaman padi gogo (anakan)

\begin{tabular}{|l|c|c|c|c|c|c|}
\hline Perlakuan & $\mathbf{2 5 \%}$ & $\mathbf{5 0 \%}$ & $\mathbf{1 0 0 \%}$ & $\mathbf{1 5 0 \%}$ & Re rata & UJBD \\
\hline Pae ngalaru & 9 & 9.67 & 9 & 10.33 & $\mathbf{9 . 5 0}$ b & $2=1,22$ \\
\hline Pae uba & 7.67 & 9 & 10.5 & 9.83 & $\mathbf{9 . 2 5}$ b & $3=1,28$ \\
\hline Pae bou & 10.83 & 11.5 & 11.67 & 11 & $\mathbf{1 1 . 2 5}$ a & $4=1,32$ \\
\hline Pae bandoeha & 8.5 & 10.83 & 9.5 & 9.67 & $\mathbf{9 . 6 3}$ b & \\
\hline Re rata & $\mathbf{9}$ & $\mathbf{1 0 . 2 5}$ & $\mathbf{1 0 . 1 7}$ & $\mathbf{1 0 . 2 1}$ & $\mathbf{9 . 9 1}$ & \\
\hline Keterangan : Angka-angka yang dikuti oleh huruf yang tidak sama pada kolom yang sama (a-b) berbeda \\
nyata pada UJBD 0,05
\end{tabular}

\section{Umur Berbunga}

Pengaruh mandiri kondisi air dan kultivar lokal terhadap umur berbunga tanaman serta hasil uji jarak berganda Duncan (UJDB) disajikan pada Tabel 7.

Tabel 7 menunjukkan bahwa kondisi air 25\% (W1) memberikan hasil paling lama terhadap rata-rata umur berbunga kultivar padi gogo yang berbeda nyata dengan kondisi air 50\% (W2), kondisi air 100\% (W3) dan kondisi air $150 \%$ (W4). Kondisi air 50\% (W2) berbeda nyata dengan kondisi air $100 \%$ (W3) dan kondisi air 150\% (W4) serta kondisi air 100\% (W3) berbeda nyata dengan kondisi air $150 \%$ (W4).Kultivar pae Uba (V2) memberikan hasil paling lama terhadap rata-rata umur berbunga yang berbeda nyata dengan kultivar pae dai Ngalaru (V1), kultivar pae Bou (V3) dan kultivar pae Bandoeha (V4). Kultivar pae Bandoeha (V4) berbeda nyata dengan kultivar 
pae Bou (V3) dan kultivar pae dai Ngalaru (V1).

Pada pengamatan kultivar Ngalaru menunjukan bunga lebih cepat dan kultivar pae Uba (V2) berbunga paling lama pada kondisi suboptimal di bandingkan dengan kultivar yang di uji dilapangan.Kultivar pae dai Ngalaru (V1) menghasilkan bunga lebih cepat pada kondisi air optimal yang tidak berbeda nyata dengan kultivar pae Bandoeha dan pae Bou. Hal ini menunjukkan bahwa setiap kultivar memiliki umur berbunga yang berbeda-beda berdasarkan pada kemampuan memanfaatkan sumberdaya lingkungan dan potensi genetik yang dimilikinya.

Tabel 7 Pengaruh mandiri kultivar dan kondisi air terhadap umur berbunga tanaman padi gogo (hari)

\begin{tabular}{|l|c|c|c|c|c|c|}
\hline Perlakuan & $\mathbf{2 5 \%}$ & $\mathbf{5 0 \%}$ & $\mathbf{1 0 0 \%}$ & $\mathbf{1 5 0 \%}$ & Rerata & UJBD \\
\hline Pae ngalaru & 84.67 & 80.33 & 77.33 & 78 & $\mathbf{8 0 . 0 8} \mathbf{d}$ & $2=0,85$ \\
\hline Pae uba & 101.33 & 101.33 & 98.33 & 91 & $\mathbf{9 8 . 0 0} \mathbf{a}$ & $3=0,90$ \\
\hline Pae bou & 85.33 & 85.33 & 84.33 & 82.67 & $\mathbf{8 4 . 4 2} \mathbf{c}$ & $4=0,93$ \\
\hline Pae bandoeha & 91.67 & 90 & 87.33 & 87.67 & $\mathbf{8 9 . 1 7} \mathbf{b}$ & \\
\hline Ra & &
\end{tabular}

\begin{tabular}{l|l|l|l|l|l|l|l}
\hline Rerata & 90.75 a & $89.25 ~ b$ & 86.83 c & $84.83 \mathrm{~d}$ & 87.92 \\
\hline
\end{tabular}

Keterangan : Angka-angka yang diikuti oleh huruf yang tidak sama pada kolom yang sama (a-b) berbeda nyata pada UJBD 0,05

\section{Umur panen}

Pengaruh mandiri kondisi air dan kultivar lokal terhadap umur panen tanaman serta hasil uji jarak berganda Duncan (UJDB) disajikan pada Tabel 8.

Tabel 8 menunjukkan bahwa kondisi air 25\% (W1) memberikan hasil paling lama terhadap rata-rata umur panen kultivar padi gogo yang berbeda nyata dengan kondisi air 50\% (W2), kondisi air 100\% (W3) dan kondisi air $150 \%$ (W4). Kondisi air 50\% (W2) tidak berbeda nyata dengan kondisi air 100\% (W3) tetapi berbeda nyata dengan kondisi air $150 \%$ (W4) serta kondisi air 100\% (W3) tidak berbeda nyata dengan kondisi air $150 \%$ (W4). Kultivar pae uba (V2) memberikan hasil paling lama terhadap rata-rata umur panen yang berbeda nyata dengan kultivar pae dai ngalaru (V1), kultivar pae bou (V3) dan kultivar pae bandoeha (V4). Kultivar pae bandoeha (V4) kultivar pae bou (V3) tidak berbeda nyata tetapi berbeda nyata dengan kultivar pae dai ngalaru (V1).

Hal ini menunjukkan bahwa kultivar yang diujikan pada kondisi kekurangan air mengalami pertumbuhan vegetatif yang terhampat sehingga untuk mencapai masa berbunga tanaman membutuhkan waktu yang lebih lama akibatnya umur panen tertunda. Pada pengamatan kultivar Ngalaru, kultivar pae Bou dan kultivar pae Bandoeha menunjukan menghasilkan bunga lebih cepat dan kultivar pae Uba (V2) berbunga paling lama pada kondisi suboptimal. Hal ini menunjukkan bahwa setiap kultivar memiliki umur panen yang berbeda-beda berdasarkan pada kemampuan memanfaatkan sumberdaya lingkungan dan potensi genetik yang dimilikinya.

Tabel 8 Pengaruh mandiri kultivar dan kondisi air terhadap umur panen tanaman padi gogo (hari)

\begin{tabular}{|l|c|c|c|c|c|c|}
\hline Perlakual & $\mathbf{2 5 \%}$ & $\mathbf{5 0 \%}$ & $\mathbf{1 0 0 \%}$ & $\mathbf{1 5 0 \%}$ & Rerata & UJBD \\
\hline Pae ngala & 121,00 & 114,67 & 110,00 & 110,00 & $113.92 \mathrm{c}$ & $2=2,618$ \\
\hline Pae uba & 125,00 & 125,00 & 123,67 & 122,33 & $124,00 \mathrm{a}$ & $3=2,751$ \\
\hline Pae bou & 119,67 & 119,67 & 122,33 & 117,00 & $119.67 \mathrm{~b}$ & $4=2,838$ \\
\hline Pae bandi & 125,00 & 119,67 & 119,67 & 117,00 & $120.34 \mathrm{~b}$ & \\
\hline Re rata & 122.67 a & $119.75 \mathrm{~b}$ & $118.92 \mathrm{bc}$ & $116.58 \mathrm{c}$ & & \\
\hline $\begin{array}{l}\text { Keterangan : Angka-angka yang diikuti oleh huruf yang tidak sama pada kolom yang sama (a-b) berbeda nyata } \\
\text { pada UJBD } 0,05\end{array}$ & & & & \\
\hline
\end{tabular}





\section{Berat 1000 Butir}

Pengaruh mandiri kultivar lokal terhadap berat 1000 butir tanaman, hasil uji jarak berganda Duncan (UJDB) disajikan pada Tabel 9.

Tabel 9 menunjukkan bahwa kultivar pae Bandoeha (V4) memberikan hasil terbaik terhadap rata-rata berat gabah 1000 butir yang berbeda nyata dengan kultivar pae dai ngalaru (V1), kultivar pae Uba (V2) dan kultivar pae Bou (V3). Kultivar pae dai Ngalaru (V1) berbeda nyata dengan kultivar pae Uba (V2) dan kultivar pae Bou (V3) serta kultivar pae Uba (V2) berbeda nyata dengan kultivar pae Bou (V3).

Hal menunjukan setiap kultivar memiliki karakter morfologis yang berbeda beda, pada kultivar pae Bandoeha memiliki bentuk biji yang besar dan panjang di bandingkan dengan kultivar pae Bou yang bijinya sangat kecil tetapi mempunyai berat biji per malai dan rumpun yang lebih baik dari kultivar pae Bandoeha.

Tabel 9 Pengaruh mandiri kultivar terhadap berat 1000 butir tanaman padi gogo $(\mathrm{g})$

\begin{tabular}{|l|c|c|c|c|c|c|}
\hline Perlakuan & $\mathbf{2 5 \%}$ & $\mathbf{5 0 \%}$ & $\mathbf{1 0 0 \%}$ & $\mathbf{1 5 0 \%}$ & Rerata & UJBD \\
\hline Pae ngalaru & 24.8 & 24.43 & 25 & 25.4 & $\mathbf{2 4 . 9 1} \mathbf{b}$ & $2=1,12$ \\
\hline Pae uba & 23.43 & 21.93 & 23.4 & 24.27 & $\mathbf{2 3 . 2 6} \mathbf{c}$ & $3=1,17$ \\
\hline Pae bou & 16.6 & 17.17 & 15.77 & 16.13 & $\mathbf{1 6 . 4 2} \mathbf{d}$ & $4=1,21$ \\
\hline Pae bandoeha & 28.93 & 29.13 & 30.27 & 29.87 & $\mathbf{2 9 . 5 5}$ a & \\
\hline Rerata & $\mathbf{2 3 . 4 4}$ & $\mathbf{2 3 . 1 7}$ & $\mathbf{2 3 . 6 1}$ & $\mathbf{2 3 . 9 2}$ & $\mathbf{2 3 . 5 3}$ & \\
\hline
\end{tabular}

Keterangan : Angka-angka yang diikuti oleh huruf yang tidak sama pada kolom yang sama (a-b) berbeda nyata pada UJBD 0,05

\section{Gabah Isi Permalai}

Pengaruh mandiri kultivar lokal terhadap gabah isi permalai tanaman serta hasil uji jarak berganda Duncan (UJDB) disajikan pada Tabel 10 .

Tabel 10 menunjukkan bahwa kultivar pae Bou (V3) memberikan hasil terbaik terhadap rata-rata gabah isi permalai yang berbeda nyata dengan kultivar pae dai Ngalaru (V1), kultivar pae Uba (V2) dan kultivar pae
Bandoeha (V4). Kultivar pae Uba (V2) berbeda nyata dengan kultivar pae dai Ngalaru (V1) dan kultivar pae Bandoeha (V4) serta kultivar pae dai Ngalaru (V1) berbeda nyata dengan kultivar pae Bandoeha (V4). Perbedaan mandiri menunjukkan bahwa kultivar terbaik memberikan hasil yang paling tinggi pada setiap kondisi air sehingga tidak terjadi interaksi antara kultivar dan kondisi air terhadap gabah isi permalai.

Tabel 10 Pengaruh mandiri kultivar terhadap gabah isi permalai tanaman padi gogo (biji)

\begin{tabular}{|l|c|c|c|c|c|c|}
\hline Perlakuan & $\mathbf{2 5 \%}$ & $\mathbf{5 0 \%}$ & $\mathbf{1 0 0 \%}$ & $\mathbf{1 5 0 \%}$ & Rerata & UJBD \\
\hline Pae ngalaru & 115.25 & 114.93 & 103.05 & 94.39 & $\mathbf{1 0 6 . 9 0}$ b & $2=15,71$ \\
\hline Pae uba & 101.33 & 122.6 & 125.1 & 112.29 & $\mathbf{1 1 5 . 3 3}$ b & $3=16,51$ \\
\hline Pae bou & 148.29 & 134.31 & 150.5 & 130.08 & $\mathbf{1 4 0 . 7 9}$ a & $4=17,03$ \\
\hline Pae bandoeha & 86.87 & 70.02 & 95.25 & 87.2 & $\mathbf{8 4 . 8 3} \mathbf{c}$ & \\
\hline Rerata & $\mathbf{1 1 2 . 9 4}$ & $\mathbf{1 1 0 . 4 6}$ & $\mathbf{1 1 8 . 4 7}$ & $\mathbf{1 0 5 . 9 9}$ & $\mathbf{1 1 1 . 9 7}$ & \\
\hline \multicolumn{2}{|c|}{ Keterangan : Angka-angka yang diikuti oleh huruf yang tidak sama pada kolom yang sama (a-b) berbeda nyata pada } \\
UJBD 0,05
\end{tabular}

\section{Gabah Hampa Permalai}

Pengaruh interaksi kondisi air dan kultivar lokal terhadap gabah hampa permalai tanaman serta hasil uji jarak berganda Duncan (UJDB) disajikan pada Tabel 11.

Tabel 11 menunjukkan bahwa kondisi air 25\% dan kultivar pae Bou (W1V3) memberikan hasil paling tinggi terhadap ratarata gabah hampa permalai yang berbeda nyata dengankondisi air $25 \%$ dan kultivar pae dai Ngalaru (W1V1), kondisi air 25\% dan kultivar pae Uba (W1V2), kondisi air 25\% dan kultivar pae Bandoeha (W1V4), Kondisi air 50\% dan kultivar pae Bou (W2V3), kondisi air 100\% 
dan kultivar pae Bou (W3V3) dan kondisi air $150 \%$ dan kultivar pae Bou (W4V3). Interaksi dalam perlakuan menunjukkan bahwa kultivar pae Bou yang memiliki gabah hampa yang sangat tinggi pada kondisi air 25\% (W1V3) mengalami penurunan gabah hampa yang signifikan ketika berada pada kondisi air 50\%, $100 \%$ dan $150 \%$.

Tabel 11 Pengaruh interaksi kondisi air dan kultivar terhadap gabah hampa permalai tanaman padi gogo (biji)

\begin{tabular}{|l|c|c|c|c|c|c|}
\hline Pe rlakuan & $\mathbf{2 5 \%}$ & $\mathbf{5 0} \%$ & $\mathbf{1 0 0} \%$ & $\mathbf{1 5 0} \%$ & Rerata & UJBD \\
\hline Pae ngalaru & $23.076 \mathrm{c}$ & $27.771 \mathrm{a}$ & $19.353 \mathrm{a}$ & $14.520 \mathrm{a}$ & $\mathbf{2 1 . 1 8}$ & $2=7.240$ \\
\hline Pae uba & $\mathrm{pq}$ & $\mathrm{p}$ & $\mathrm{p}$ & $\mathrm{q}$ & & $3=7.547$ \\
\hline & $42.233 \mathrm{~b}$ & $31.711 \mathrm{a}$ & 19.300 a & $15.575 \mathrm{a}$ & $\mathbf{2 7 . 2 0 5}$ & $4=7.754$ \\
\hline Pae bou & $\mathrm{p}$ & $\mathrm{q}$ & $\mathrm{r}$ & $\mathrm{r}$ & & \\
\hline Pae bandoe & $49.533 \mathrm{a}$ & $18.620 \mathrm{~b}$ & $18.172 \mathrm{a}$ & $11.688 \mathrm{~b}$ & $\mathbf{2 4 . 5 0 3}$ & \\
\hline & $\mathrm{p}$ & $\mathrm{q}$ & $\mathrm{q}$ & $\mathrm{q}$ & & \\
\hline Re rata & $18.733 \mathrm{c}$ & $31.333 \mathrm{a}$ & $\mathbf{6 . 3 4 9} \mathrm{b}$ & $9.116 \mathrm{a}$ & $\mathbf{1 6 . 3 8 3}$ & \\
\hline Keterangan : Angka-angka yang diikuti oleh huruf yang tidak sama pada kolom yang sama (a-b) dan \\
\hline
\end{tabular}

\section{Gabah Isi Perumpun}

Pengaruh mandiri kondisi air terhadap gabah isi perumpun tanaman serta hasil uji jarak berganda Duncan (UJDB) disajikan pada Tabel 12.

Tabel 12 menunjukkan bahwa kondisi air $100 \%$ (W3) memberikan hasil terbaik terhadap rata-rata gabah isi perumpun pada berbagai kultivar padi gogo yang diuji, berbeda nyata dengankondisi air $25 \%$ (W1) dan kondisi air $150 \%$ (W4) tetapi tidak berbeda nyata dengan kondisi air 50\% (W2). Kondisi air $50 \%$ (W2) berbeda nyata dengankondisi air $25 \%$ (W1) tetapi tidak berbeda nyata dengan kondisi air $150 \%$ (W4) serta kondisi air $150 \%$ (W4) tidak berbeda nyata dengan kondisi air 25\% (W1). Pengaruh mandiri menunjukkan bahwa kondisi air $100 \%$ dan $50 \%$ memberikan hasil gabah isi perumpun yang tinggi pada semua kultivar yang diujikan sehingga tidak terjadi interaksi antara kondisi air dan kultivar padi gogo local.
Hasil penelitian gabah isi perumpun menunjukkan bahwa kondisi air 100\% memiliki gabah isi perumpun yang tertinggi dan terendah pada kondisi air 25\%. Gabah isi perumpun menjadi gambaran besaran produksi tanaman. Tanaman yang memiliki gabah isi perumpun yang tinggi akan menghasilkan produksi yang besar. Tingginya gabah isi perumpun sejalan dengan hasil pengamatan pada tinggi tanaman dan jumlah anakan yang memiliki nilai tertinggi pada kondisi air $100 \%$. Tanaman yang pertumbuhan vegetatifnya optimal akan menghasilkan produksi yang optimal karena pertumbuhan vegetatif menjadi proses awal akumulasi energi untuk pembentukan biji. Pembentukan biji atau gabah pada tanaman padi sangat ditentukan oleh ketersedian air dan kemampuan tanaman menyerap energi matahari serta hara dalam tanah.

Tabel 12 Pengaruhmandiri kondisi air terhadap gabah isi perumpun tanaman padi

\begin{tabular}{|c|c|c|c|c|c|c|}
\hline Perlakuan & $25 \%$ & $\mathbf{5 0 \%}$ & $100 \%$ & $150 \%$ & Rerata & UJBD \\
\hline Pae ngalaru & 46.8 & 51.58 & 52.55 & 48.65 & 49.89 & $2=3,44$ \\
\hline Pae uba & 43.3 & 45.88 & 52.55 & 50.61 & 48.08 & $3=3,62$ \\
\hline Pae bou & 47.8 & 51.6 & 52.77 & 47.61 & 49.95 & $4=3,73$ \\
\hline Pae bandoehs & 45.27 & 50.82 & 51.11 & 47.28 & 48.62 & \\
\hline
\end{tabular}

\begin{tabular}{llllll}
\hline Rerata & 45.79 c & 49.97 ab & 52.25 a & 48.54 bc
\end{tabular}

Keterangan : Angka-angka yang diikuti oleh huruf yang tidak sama pada kolom yang sama (a-b) berbeda nyata pada UJBD 0,05 


\section{KESIMPULAN}

Berdasarkan hasil penelitian yang dilaksanakan dapat disimpulkan bahwa, 1. Volume air $100 \%$ dan kultivar pae dai Ngalaru memberikan pengaruh interaksi sangat nyata terhadap tinggi tanaman, kondisi air $100 \%$ dan kultivar pae Bou memberikan pengaruh nyata pada jumlah anakan, volume air $50 \%$ dan kultivar pae Uba memberikan pengaruh lebih baik pada jumlah daun, dan kondisi air $25 \%$ dan kultivar pae Bou

\section{DAFTAR PUSTAKA}

Abdullah B., H. Safitri, dan Sularjo. 2007. Penampilan Galur Harapan Padi Tipe Baru di Jawa dan Bali.Apresiasi Hasil Penelitian Padi

Allard,W. 1960. Principles of Plant Breeding.Jhon Wiley and sons Inc. New York. 75p.

Badan Penelitian dan Pengembangan Pertanian.2009.Pengelolaan Tanaman Terpadu Padi Gogo.Badan Penelitian dan Pengembangan Pertanian. Jakarta. 28 hal.

Badan Pusat Statistik Sultra, 2014. Produksi Padi dan Palawija (Angka Tetap 2012 dan 2013).Provinsi Sulawesi Tenggara.

Bawolye, J. 2006. Bahan Organik dan Pupuk Kandang. Sumber: IRRI Rice Knowledge Bank (masukan dari V.Balasubramanian dan M.Bell) http://www.pustakadeptan.go.id/publi kasi/wr276057.pdf $\quad[30$ Agustus 2008].

Direktorat Perbenihan dan Sarana Produksi. 2008. Syarat Teknis Minimal Anorganik vs Pupuk Organik. http:/ditjenbun.deptan.go.id/benihbun/ benih [30 Agustus 2008].

Istiqomah, N., Handoko dan Indriana R.D. 2012. Kajian Pengunaan Varietas Padi Gogo di Lahan Sawah Mendukung Peningkatan Produksi Padi. Seminar Nasional Kedaulatan Pangan dan Energi. Balai Pengkajian Teknologi Pertanian. Jawa Timur. Hal 1-4 memberikan gabah hampa per malai paling tinggi.

2. Secara umum perlakuan volume air $50 \%$, $100 \%$ dan $150 \%$ memberikan pengaruh lebih baik terhadap pertumbuhan dan produksi padi gogo lokal.

3. Padi gogo lokal kultivar pae dai Ngalaru memperlihatkan respon pertumbuhan dan produksi yang lebih baik pada tinggi tanaman, umur berbunga, jumlah anakan, berat kering tajuk, berat kering akar, gabah isi per rumpun, dan berat seribu butir.

Jumin, H. B. 2008. Dasar-dasar Agronomi. Rajagrafindo Persada. Jakarta. 249 hal.

Leomo S. Sutariati GAK, Agustina, 2012. Uji Kombinasi Pupuk Organik dan Anorganik dalam Pola LEISA Terhadap Pertumbuhan dan Hasil Tanaman Sorgum Lokal pada Lahan Marginal. Jurnal Agroteknos. November 2012. Vol. 2.No. 3.Hal.166-174.

Liu, G. F. J,Yang, H. M. XuA, Y. Hayat, dan J. Zhu. 2008. Genetic analysis of grain yield conditioned on its component traits in rice (Oryza sativa L.). Australian Journal of Agricultural Research, Vol 59, 189-195

Lubis, E., R. Hermanasari, Sunaryo, A. Santika dan E. Suoarman. 2008. Toleransi Padi Gogo Terhadap Cekaman Abiotik.Prosiding Seminar Apresiiasi Hasil Hasil Penelitian Padi Menunjang P2BN Buku 2. Balai Besar Penelitian Tanaman Padi Badan Litbang Departemen Pertanian. 962 hal.

Makarim, A.K dan E. Suhartatik. 2009. Morfologi dan Fisiologi Tanaman Padi. Balai Besar Penelitian Tanaman Padi. 50 halaman

Nasih. 2006. Pupuk Organik. Universitas Gajah Mada. nasih@ugm.ac.id [30 Agustus 2008].

2006. Pupuk Hayati. Universitas Gajah Mada.nasih@ugm.ac.id [7 Juli 2009].

Nazirah, L. 2008. Tanggap Beberapa Varietas Padi Gogo Terhadap Interval dan 
Tingkat Pemberian air [Tesis]. Sekolah Pascasarjanan. Universitas Sumatra Utara. Medan.

Rahayu Yugi A dan Harjoso T. 2010.Karakter Agronomis dan Fisiologis Padi Gogo yang ditanam pada Media Tanah Bersekam pada Kondisi Air di bawah Kapasitas Lapang.Fakultas pertanian Universitas Jenderal Soedirman. Akta Agrosia. 13. 40-49.

Sadimantara. 2007. Evaluasi Ketahanan Plasma Nutfah Padi Gogo lokal Asal Kabupaten Muna Terhadap Cekaman Kekeringan. Fakultas Pertanian Unhalu Kendari

Sadimantara, 2012.Karaterisasi Morfologi Ketahanan Kekeringan Plasma Nutfah Padi Gogo Lokal Asal Sulawesi Tenggara.Jurnal Agroteknos Maret 2012 Vol.2.No.1.hal. 50-56

Sadimantara, G.R dan Muhidin.2012. Karakterisasi Morfologi Ketahanan Kekeringan Plasma Nutfah Padi Gogo Lokal Asal Sulawesi Tenggara. Jurnal Agroteknos Vol 2(2) : 81-92

Sadimantara, 2013. Seleksi Beberapa Progeny Hasil Persilangan Padi Gogo (Oryza sativa L.) Berdasarkan Karakter Pertumbuhan Tanaman. Jurnal Agroteknos. Vol. 3.No. 1.Hal. 48-52

Sadimantara, 2014. Perbaikan Sifat Genetik Tanaman Padi Gogo: Upaya Mewujudkan Ketahanan Pangan Menuju Kedaulatan Pangan Berkelanjutan. Pidato Ilmiah pada Rapat Senat Terbuka dalam rangka Pengukuhan Guru Besar di Lingkungan Universitas Halu Oleo.

Setyorini, A. dan S. Abdulrahman.2008. Pengelolaan Hara Mineral Tanaman Padi.Dalam Suyamto (eds). 2008. Padi Inovasi Teknologi dan ketahanan Pangan.Balai Besar Penelitian Tanaman padi Badan Litbang Departemen Pertanian.499 hal.

Simanungkalit, R. D. M. dan D. A. Suradikarta. 2006. Pupuk Organik dan Pupuk
Hayati. Balai Besar Penelitian dan Pengembangan Sumberdaya Lahan Pertanian . Bogor. 283 hal.

Sugiyanta.2007. Peran Jerami dan Pupuk Hijau terhadap Efisiensi dan Kecukupan Hara Lima Varietas Padi Sawah.Disertasi.Institut Pertanian Bogor.

Sulistyono, Eko. Suwarto dan Yulianti Ramdiani. $2005 . \quad$ Defisit Evapotranspirasi sebagai Indikator Kekurangan Air pada Padi Gogo.Bul.Agron. (33) (1) 6-11

Sutariati, et al. 2014.Invigorasi Benih Padi Gogo Lokal untuk Meningkatkan Vigor dan Mengatasi Permasalahan Dormansi Fisiologi Pascapanen.Jurnal Agroteknos maret 2014.Vol. 4.No. 1.Hal.10-17.

Syamsiyah, S. 2008. Respon Tanaman Padi Gogo terhadap Stres Air dan Inokulasi Mikoriza.Skripsi.Institut Pertanian Bogor.

Toha, M. Husin. 2005. Padi Gogo dan Pola pengembangannya. Balai Penelitian dan Pengembangan pertanian Departemen Pertanian

Tri Harjoso, Siti N. dan Ahadiyat Y.R. 2011. Karakter Morfologi Padi Pertanaman dengan Pendekatan SRI (system of Rice Intensification. Jurnal Agrin Vol. $15 / 2$. Program studi agroteknologi. Fakultas Pertanian. Universitas Jenderal Soedirman. Purwokerto.

United State Department of Agriculture. 2007. Konsumsi dan Stok Beras di Beberapa Negara, 2003-2007. Dalam Data Penting Padi Dunia dan Beberapa Negara Asia.BPPTP dan IRRI. Bogor.

Wibowo, Akhamad Yudi. 2008. Pengujian Keragaan Karakter Agronomi Galurgalur Harapan Padi Sawah Tipe Baru (Oryza sativa L). Skripsi.Institut Pertanian Bogor. P.53

Widyastuti, Yuni. Indrastuti AR., dan Satoto. 2007. Studi Keragaman Genetik Karakter Bunga yang Mendukung Persilangan Alami Padi.Penelitian Pertanian Tanaman Pangan vol. 26 no. 1 . 
J. Berkala Penelitian Agronomi 6 (2) : 25 - 36 (2018)

Wijayanto, 2013. Prospek Penerapan

Bioteknologi dalam Pemanfaatan dan Pengembangan Biodiversitas Padi Lokal Sulawesi Tenggara. Jurnal Agroteknos Maret 2013. Vol. 3.No. 1.Hal.41-47.
Yoshida, S. 1981. Fundamental of Rice Crop.Science.IRRI. Los Banos. Philippine s.269 